\title{
Comparative Aspects of Canine and Human Inflammatory Breast Cancer
}

Teresa P. Raposo, DVM, MSc, $\mathrm{PhD}^{\mathrm{a}}$, Hugo Arias-Pulido, $\mathrm{PhD}^{\mathrm{b}}$, Nabila Chaher ${ }^{\mathrm{c}}$, MD, Steven N. Fiering, PhD ${ }^{d}$, David J. Argyle, BVMS, PhD, DECVIM-CA (Oncology), FRSE FRCVS ${ }^{e}$, Justina Prada DVM, MSc, PhD ${ }^{\mathrm{f}, \mathrm{g}}$, Isabel Pires DVM, MSc, PhD ${ }^{\mathrm{f}, \mathrm{g}}$, Felisbina Luísa Queiroga FL DVM, MSc, $\mathrm{PhD}^{\mathrm{f}, \mathrm{h}, \mathrm{i} *}$

a - Division of Cancer and Stem Cells, University of Nottingham, United Kingdom; b Department of Microbiology and Immunology. Geisel School of Medicine at Dartmouth, Lebanon, New Hampshire 03756, USA; c - Department of Pathology, Centre Pierre et Marie Curie, 1, Avenue Battendier, Place May 1st, Algiers, Algeria; d - Department of Microbiology and Immunology, Department of Genetics, and Norris Cotton Cancer Center. Geisel School of Medicine at Dartmouth, Lebanon, New Hampshire 03756, USA; e - The Royal (Dick) School of Veterinary Studies and Roslin Institute, Easter Bush Campus, Midlothian, University of Edinburgh, United Kingdom; f - Departament of Veterinary Sciences, University of Trás-os-Montes and Alto Douro, Vila Real, Portugal; g- Animal and Veterinary research Centre (CECAV), University of Trás-os-Montes and Alto Douro, Vila Real, Portugal; h- Center for the Study of Animal Sciences, CECA-ICETA, University of Porto, Porto, Portugal; i- Center for Research and Technology of Agro-Environment and Biological Sciences, University of Trás-os-Montes and Alto Douro, Vila Real, Portugal

Corresponding author* - Felisbina Luísa Queiroga, Departament of Veterinary Sciences, University of Trás-os-Montes and Alto Douro, Quinta de Prados, Vila Real, Portugal e-mail: fqueirog@utad.pt; Tel: 00351259350633 


\begin{abstract}
Inflammatory breast cancer in humans (IBC) is the most aggressive form of mammary gland cancer and shares clinical, pathological and molecular patterns of disease with canine inflammatory mammary carcinoma (CIMC). Despite the use of multimodal therapeutic approaches, including targeted therapies, the prognostic for IBC/CIMC remains poor. The aim of this review is to critically analyze IBC and CIMC in terms of biology and clinical features. While rodent cancer models have formed the basis of our understanding of cancer biology, the translation of this knowledge into improved outcomes has been limited. However, it is possible that a comparative "one health" approach to research, using a natural canine model of the disease, may help advanced our knowledge on the biology of the disease. This will translate into better clinical outcomes for both species. We propose that CIMC has the potential to be a useful model for developing and testing novel therapies for IBC. Further, this strategy could significantly improve and accelerate the design and establishment of new clinical trials to identify novel and improved therapies for this devastating disease in a more predictable way.
\end{abstract}

Keywords: Inflammatory breast cancer; Comparative Oncology; Dog

\title{
1. Introduction
}

Dogs spontaneously develop cancers that share the biology and heterogeneity of cancers found in humans, including many clinical, molecular and pathological characteristics. Canine cancers are often relatively large tumors that develop spontaneously in large outbred mammals; are genetically complex and diverse; exist in the presence of an intact immune system, with complex interactions between the host immune system and tumor cells; have significant tumor heterogeneity both within patients and between patients; develop therapeutic resistance and metastasize to distant sites. The natural history and potential clinical use of cancers in companion dogs in general is out of the scope of this review, and have been extensively reviewed elsewhere [1-4].

Inflammatory breast cancer in humans (IBC) and the corresponding canine disease, canine inflammatory mammary carcinoma (CIMC), are the most aggressive type of mammary cancer in both species with short survival times after diagnosis [4-6]. In humans, IBC was first described in 1814 by Charles Bell as a painful breast tumor with a poor prognosis, presenting purple discoloration of the overlying skin [7]. In 1924 the designation "inflammatory breast cancer" was applied by Lee and Tannenbaum, who provided a clinical 
description of the malignancy [8]. IBC is a rare and highly metastatic type of breast cancer comprising less than $3 \%$ of human breast cancer cases in the USA [9] with higher incidence observed in Northern Africa where the incidence varies from approximately $7 \%$ in Tunisia [10] to $11 \%$ in Egypt [11]. The reasons of such high incidence in this part of the world remain unknown. IBC is primarily a clinical adjunct to the histopathological diagnosis of breast cancer. IBC presents unique histopathological and clinical features for both humans and animals: edema, erythema, firmness, painful sensation, warmth of the mammary glands coupled with histological confirmation of tumor invasion of dermal lymphatic vessels $[12,13]$. Inflammatory mammary carcinoma in companion animals was initially described in dogs [14] and more recently in cats [15]. In a study at the Complutense University in Madrid, Spain, the reported prevalence of CIMC among dogs presenting for local consultation with mammary gland tumors and dysplasias was reported to be 7.6\% [16]. Based on clinical and histological similarities, the possibility of using CIMC as a model to study IBC has been proposed by several authors [16-19]. The comparative aspects between IBC and CIMC including the etiology, molecular biology, diagnosis, treatment and prognosis, supporting the rationale for using CIMC as a model for IBC are summarized and analyzed in Table 1 $[6,14,20-52]$. The effect of hormones on the etiology of CIMC and IBC is summarized in Table 2 [53-60] 


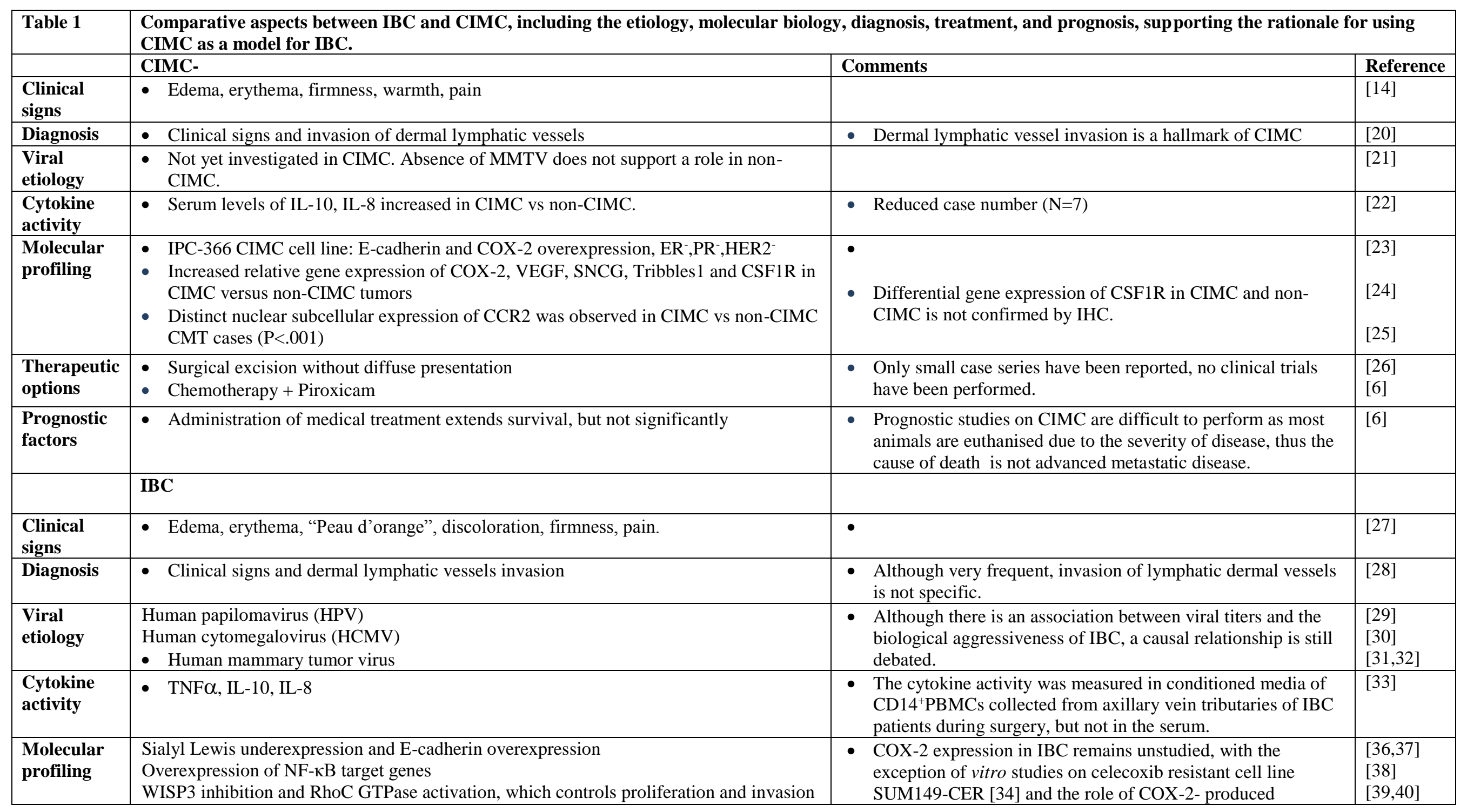




\begin{tabular}{|c|c|c|c|}
\hline & $\begin{array}{l}\text { Repression of TGF- } \beta \\
\text { Mutated genes associated with apoptosis inhibition and cell cycle: TP53 (62\%), MYC } \\
(32 \%) \\
\text { Overexpression of the translation initiation factor eIF4GI in most IBCs } \\
\text { - PD-L1 overexpression is frequent in IBC ( } 38 \%)\end{array}$ & $\begin{array}{l}\text { prostaglandin EP4 in regulating invasion and proliferation of } \\
\text { SUM149 [35] }\end{array}$ & $\begin{array}{l}{[41]} \\
{[42]} \\
{[43]} \\
{[44]}\end{array}$ \\
\hline $\begin{array}{l}\text { Therapeutic } \\
\text { options }\end{array}$ & $\begin{array}{l}\text { Taxane-anthracycline-based neoadjuvant chemotherapy, surgery, radiotherapy } \\
\text { For ER }{ }^{+} \text {Patients, } 5 \text {-year tamoxifen or aromatase inhibitors depending on their } \\
\text { menopausal state } \\
\text { - Neoadjuvant bevacizumab, trastuzumab, and chemotherapy for primary HER } 2^{+} \text {IBC }\end{array}$ & $\bullet$ & $\begin{array}{l}{[45]} \\
{[46]} \\
{[47]} \\
\end{array}$ \\
\hline $\begin{array}{l}\text { Prognostic } \\
\text { factors }\end{array}$ & $\begin{array}{l}\text { Triple negative hormone receptor status predicts poor survival } \\
\text { In a TNBC cohort, IBC status is not an independent predictor of recurrence or overall } \\
\text { survival } \\
\text { EGFR } \\
\text { Stromal VEGients have worse prognosis } \\
5 \text {-miRNA signature comprisising miR- } 421, \text { miR- } 486, \text { miR-503, miR- } 720 \text { and miR-1303 } \\
\text { predictive for IBC phenotype with an overall accuracy of } 89 \% \text {. } \\
\text { - PD-L1 overexpression in IBC predicts complete pathological response to } \\
\text { chemotherapy }\end{array}$ & $\bullet$ & $\begin{array}{l}{[48]} \\
\\
{[49]} \\
{[50]} \\
{[51]} \\
{[47,52] .} \\
{[44]}\end{array}$ \\
\hline
\end{tabular}

BCSS, Breast Cancer Specific Survival; CMT - Canine Mammary Tumors; DFS - Disease Free survival; EGFR,epidermal growth factor receptor; IBC,

inflammatory breast cancer; IHC, immunohistochemistry; PR, progesterone receptor; MMTV, mouse mammary tumor virus 


\begin{tabular}{|c|c|c|c|c|}
\hline Table 2 & $\begin{array}{l}\text { Hormones and } \\
\text { receptors }\end{array}$ & Results/Observations & Comment & Reference \\
\hline \multirow[t]{12}{*}{ CIMC } & $\mathrm{ER} \alpha$ & - All CIMC cases were ER $\alpha$ negative & $\begin{array}{l}\text { ER } \alpha \text { detected in normal mammary gland } \\
(5 / 5,100 \%)) \text { and few non-inflammatory } \\
\text { malignant CMT }(2 / 32,6.3 \%) \text { but not in } \\
\text { CIMC }\end{array}$ & $\begin{array}{l}{[53-55]} \\
1\end{array}$ \\
\hline & $\mathrm{ER} \beta$ & $\begin{array}{l}\text { - In CIMC cases, ER } \beta \text { positive tumors were also AR positive. } \\
\text { - Significant increases ER } \beta(\mathrm{P}=.038) \text { in } \mathrm{CIMC}(\mathrm{N}=21) \text { versus non- } \\
\text { CIMC }(\mathrm{N}=19) \text { by immunohistochemistry. }\end{array}$ & $\begin{array}{l}\text { Progressive increases in ER } \beta \text { suggest a } \\
\text { role in CIMC carcinogenesis }\end{array}$ & {$[54,56]$} \\
\hline & PR & $\begin{array}{l}\text { - Significantly increased expression in CIMC }(\mathrm{N}=21) \text { versus non- } \\
\text { CIMC }(\mathrm{N}=19) \text { by immunohistochemistry }(\mathrm{P}=.0037) \text {. }\end{array}$ & $\begin{array}{l}\text { - PR could also be involved in CIMC } \\
\text { carcinogenesis }\end{array}$ & {$[56]$} \\
\hline & HER2/neu & - HER2/neu significance is unclear & $\begin{array}{l}\text { - Caution is advised with adapting FDA } \\
\text { approved kits for human HER2/neu } \\
\text { detection }\end{array}$ & {$[57,58]$} \\
\hline & AR & $\begin{array}{l}\text { Majority of CIMC showing positivity for AR (13/14), versus }(27 / 32) \\
\text { of non-CIMC tumors, most of which had low-moderate levels of } \\
\text { expression } \\
\text { - No statistically significant increases observed in terms of total score } \\
\text { (Alfred system) for AR in CIMC }(95.2 \% \text { positive, 20/21) relative to } \\
\text { non-CIMC }(89.5 \%, 17 / 19)\end{array}$ & $\begin{array}{l}\text { Disparity in AR findings, possibly due to } \\
\text { different methodology. Reduced numbers } \\
\text { of CIMC cases for both groups. }\end{array}$ & {$[54]$} \\
\hline & Aromatase & $\begin{array}{l}\text { - Significant increases in aromatase }(\mathrm{P}=.025) \text { in } \mathrm{CIMC}(\mathrm{N}=21) \text { versus } \\
\text { non-CIMC }(\mathrm{N}=19) \text { by immunohistochemistry }\end{array}$ & $\begin{array}{l}\text { - Progressive increases of aromatase } \\
\text { suggest a role in CIMC carcinogenesis. }\end{array}$ & {$[56]$} \\
\hline & Androstenedione & \multirow{6}{*}{$\begin{array}{l}\text { Serum and tumor tissue homogenates hormonal levels significantly } \\
\text { higher in CIMC relative to non-CIMC } \\
\text { Serum and tumor homogenates levels correlate, with the exception of } \\
\text { 17ß-Estradiol, which had lower serum levels in CIMC relatively to } \\
\text { non-CIMC }\end{array}$} & \multirow{6}{*}{$\begin{array}{l}\text { - Small number of CIMC cases for both } \\
\text { studies }(\mathrm{n}=7,[53], \mathrm{n}=7[54]) \\
\text { - Benign tumors not included [54] } \\
\text { Only measured hormonal levels in tumor } \\
\text { tissue homogenates by ELISA[53] }\end{array}$} & \multirow[t]{6}{*}[53,54]{} \\
\hline & DHEA & & & \\
\hline & $17 \beta$-Estradiol & & & \\
\hline & Progesterone & & & \\
\hline & Testosterone & & & \\
\hline & Estrone sulfate & & & \\
\hline
\end{tabular}




\begin{tabular}{|c|c|c|c|c|}
\hline $\begin{array}{l}\text { Table } 2 \\
\text { (cont.) }\end{array}$ & $\begin{array}{l}\text { Hormones and } \\
\text { receptors }\end{array}$ & Results/Observations & Comment & Reference \\
\hline \multirow[t]{12}{*}{ IBC } & $\mathrm{ER} \alpha$ & \multirow{4}{*}{$\begin{array}{l}26 \% \text { Triple negative }\left(\mathrm{ER}^{-}, \mathrm{PR}^{-}, \mathrm{HER} 2^{-}\right) \\
34 \% \text { Triple negative ( } 17 \% \text { basal-like, } 17 \% \text { claudin-low) }\end{array}$} & \multirow{4}{*}{$\begin{array}{l}\text { Only ER } \alpha \text { is analysed in ER immunoexpression in } \\
\text { IBC by immunohistochemistry. }\end{array}$} & \multirow{4}{*}{$\begin{array}{l}{[59]} \\
{[60]}\end{array}$} \\
\hline & $E R \beta$ & & & \\
\hline & PR & & & \\
\hline & HER2/neu & & & \\
\hline & AR & \multirow[t]{2}{*}{ Not yet investigated in IBC } & & \\
\hline & Aromatase & & & \\
\hline & Androstenedione & \multirow{6}{*}{ Serum levels of steroid hormones and prolactin are yet investigated in IBC. } & & \\
\hline & DHEA & & & \\
\hline & $17 \beta$-Estradiol & & & \\
\hline & Progesterone & & & \\
\hline & Testosterone & & & \\
\hline & Estrone sulfate & & & \\
\hline
\end{tabular}

AR - Androgen Receptor; ER -- estrogen receptor, PR - progesterone receptor; DHEA - dehydroepiandrosterone 


\section{Etiology}

\subsection{Endocrine etiology}

The etiology of both IBC and CIMC is multifactorial, resulting from a combination of hormonal changes, accumulated genetic mutations [5] and environmental factors [61-63]. Several studies have been performed using canines to detect the expression of steroid hormones and their receptors that could be implicated in the genesis of the abnormal mammary epithelial proliferation observed in CIMC and in canine mammary tumors overall [53-55]. Expression of estrogen receptor alpha $(E R \alpha)$, estrogen receptor beta $(E R \beta)$ and androgen receptor (AR) was evaluated by immunohistochemistry in a series of CIMC and non-CIMC tumors [54]. In all CIMC cases $(\mathrm{N}=14), \mathrm{ER} \alpha$ expression was absent and 13/14 $(93 \%)$ of cases were ER $\beta$ and also AR positive. Moreover, AR expression in CIMC was increased relative to non-CIMC and normal mammary gland [54]. A more recent study [56], using a quantitative scoring system generated by adding the percentage of positive cells and the intensity of immunolabelling (total score expressed as mean \pm S.E.M.) showed significant increases in immunohistochemistry staining for aromatase $(\mathrm{P}=.025)$, an enzyme that converts androgens to estrogens in situ [64], and also $\operatorname{ER} \beta(\mathrm{P}=.038)$ and progesterone receptor $(\mathrm{PR})$ $(\mathrm{P}=.0037)$ in CIMC $(\mathrm{n}=21)$ versus non-CIMC $(\mathrm{n}=19)$. However no differences were found for expression of AR between CIMC and non-CIMC [56]. This disparity in AR results studies $[54,56]$ could be explained by the differences in scoring systems and tumor series used, as well as by an increase in the conversion of androgens to estrogens in CIMC through abundant aromatase expression and subsequent down-regulation of AR in the study by de Andres et al.

Hormone serum levels of dehydroepiandrosterone, androstenedione, testosterone, progesterone and estrone sulfate were significantly higher in CIMC than in non-CIMC samples $[53,54]$. The abundance of steroid hormones might be an important contributing factor in the pathogenesis of CIMC by mechanisms of paracrine and/or autocrine action. Estrone sulfate in particular may be converted into estrone and estradiol by the enzyme steroid sulfatase [65] or can directly transactivate estrogen and androgen receptors [66] therefore magnifying the effects of steroid hormonal regulation in CIMC.

In IBC, to the best of our knowledge, detailed imunoexpression of $\mathrm{ER} \alpha$ and $\beta, \mathrm{AR}$ and aromatase have not yet been reported in the literature. Of note, steroid hormones levels, including progesterone, androstenedione, testosterone, $17 \beta$-estradiol and estrone sulfate levels have been shown to be higher in the conditioned media of the IBC cell line SUM149 than in the CIMC cell line IPC-366 by ELISA immunoassay [67]. This study demonstrated in 
vitro secretion of steroid hormones (progesterone, androstenedione, testosterone, $17 \beta$ estradiol and estrone sulfate) [67], suggesting a role for hormonal regulation in IBC. However, studies with clinical samples, including tumor tissue and serum from patients with non-IBC and patients with IBC would be required to confirm this hypothesis and overcome the inherent limitations associated with in vitro conditions.

\subsection{Viral etiology}

Regarding the role of infectious agents in the etiology of breast cancer, viral infections by high-risk human papillomavirus (HPV) have been identified in metaplastic mammary carcinomas [30], but a causal relationship has not been established. In patients with IBC, titers of human cytomegalovirus (HCMV) IgG antibodies were found to be higher than in non-IBC patients. The presence of HCMV has been suggested to be linked to the etiology and pathogenesis of IBC with HCMV playing an oncomodulatory role by infecting adjacent tissues, leading to overexpression and activation of NF- $\kappa \mathrm{B} / \mathrm{p} 65[29,68,69]$. To support this hypothesis, A recent study that enrolled 91 patients with non-IBC and 44 with IBC reported DNA from HCMV and HPV-16 were the most detected viral DNAs in breast carcinoma tissues, although the frequency and prevalence of HCMV and human herpes virus type 8 (HHV-8) DNA were significantly higher in IBC than non-IBC tissue [70]. However, the high incidence found in this study could be due to cross-contamination during the handling and processing of tissue samples, and the isolation of viral DNA, as the measures to prevent cross-contamination were not disclosed, therefore casting doubt on its results. The absence of papillomavirus DNA has been confirmed in normal canine mammary gland $(\mathrm{N}=5)$ and canine mammary tumors $(\mathrm{CMT})(\mathrm{N}=27)$. Whilst this suggests these viruses are not associated with canine mammary carcinogenesis, the small numbers of cases studied makes it impossible to rule out [71].

Mouse mammary tumor virus-like sequences (MMTV) have been associated with human breast cancer [72-74]. These sequences were also found in CMT at similar frequencies in normal, benign and malignant CMTs, suggesting that MMTV is not causally associated with CMT [21]. Overall, the involvement of viruses in breast cancer, including IBC, remains unclear [75,76]. Given the influence of viruses in cancer [77], and in particular the oncogenic role of MMTV in murine mammary carcinogenesis [78-80], further research is warranted to determine the possible role of viruses in the malignant transformation of mammary gland cells of both dogs and humans. 


\section{Molecular biology of Inflammatory Breast Cancer}

\subsection{Inflammatory microenvironment}

During carcinogenesis, malignant transformation is triggered by the accumulation of DNA mutations [81]. Some have suggested the high level of inflammation observed in IBC may serve to increase genetic instability and its associated DNA damage, promoting the malignant phenotype by increasing mutation rates $[82,83]$.

Considering IBC or CIMC as types of cancer with flaring inflammation, the expression of diverse cytokines and inflammatory mediators has been evaluated to determine their role in the severity of the disease. In CIMC, a study analyzing the presence of several cytokines in the serum and tissue homogenates of CIMC $(n=7)$, malignant non-CIMC $(n=24)$, mammary-gland hyperplasia $(n=7)$ and benign tumors $(n=10)$ reported higher IL-10 and IL-8 serum levels in CIMC tumors than in the other groups, whereas in tumor-tissue homogenates, only IL-10 was significantly higher in CIMC than in the other groups, indicating a role for immunosuppression in the progression of CIMC [22]. One of the main limitations of this study was the low number of tumors present in each of the groups considered.

Immunohistochemistry of tumors from 27 women with IBC found infiltration by $\mathrm{CD} 14^{+}$tumor-associated macrophages (TAMs) to be significantly more intense than in tumors from 39 women with non-IBC (IBC, 59.3\% vs. non-IBC, 25.3\%; P=.021). Additionally, in the same patient samples, cytokine profiling of the supernatant of CD14 ${ }^{+}$ cells drained from axillary tributaries during surgery revealed significantly higher levels of TNF- $\alpha(\mathrm{P}=.002), \mathrm{MCP}-1 / \mathrm{CCL} 2(\mathrm{P}=.003), \mathrm{IL}-10(\mathrm{P}=.013)$, and IL-8 in IBC $(\mathrm{P}=.039)$ as compared to CD14+ TAMs isolated from the axillary tributaries of patients with non-IBC tumors [33]. These authors have also shown that in vitro treatment with recombinant TNF- $\alpha$, IL-10 or IL-8 significantly increased motility and invasion of IBC cancer cell lines [33]. This fact adds value to the importance of the macrophage infiltration in IBC and how the secreted cytokines may contribute to increases in migration and invasion. Furthermore, Cohen and colleagues have demonstrated that treatment with T-cell and PBMC-conditioned media, rich in TNF- $\alpha$, IL-6 and TGF- $\beta$ could induce epithelial to mesenchymal transition (EMT) in IBC cell lines SUM-149, SUM-190, IBC-3 and KPL-4 [84]. However, this study did not evaluate the role of T-cell secreted factors in vivo, in circumstances where cohesive E-cadherin overexpressing emboli form and where EMT does not have such a preponderant role in IBC metastasis. 
These comparable observations suggesting a role for inflammatory cell infiltration and cytokine production in IBC and CIMC contribute to the growing body of evidence suggesting the value of CIMC as a model for the corresponding human disease [17]. The concept of TAMs and tumor-infiltrating T-cells as important elements in the establishment of a tumor-favorable microenvironment is also strengthened. Research on the role of cytokines and chemokines in the biological behavior of both IBC and CIMC could contribute to a better understanding of this disease and lead to the development of more efficient, targeted therapies to improve the current standard of care.

\subsection{Epithelial to mesenchymal transition (EMT)}

Extensive metastasis is a prominent aspect clinical progression of IBC and it is hoped that this will provide a target for novel therapies. Studies performed in IBC have explored the process of metastasis and the potential to identify new targets for intervention $[36,37]$ with a focus on the mechanisms involved in epithelial to mesenchymal transition (EMT).

TGF- $\beta$ is a major inducer of EMT during embryological development, cancer and diseases involving chronic wound healing or fibrosis [85]. In response to TGF- $\beta$, many transcription factors regulating EMT are activated, including Twist1, SMAD, Zeb1 and 2 and Snail1 and 2 [85]. In IBC, however, EMT does not seem to have an important role in the process that enables cell migration and metastasis, given the lower levels of expression of TGF $\beta$ and the SMAD transcription factor in IBC versus non-IBC samples $[60,86]$.

One hypothesis to explain the apparent EMT-independent migration and metastasis of IBC is that attenuation of TGF- $\beta$ and in turn SMAD signaling causes a shift from singlecell motility to a cohesive type of cluster migration with clustering mediated by E-Cadherin, leading primarily to the invasion of lymph vessels [60]. This hypothesis is supported by the differential expression of E-cadherin and the mechanisms involved in the cohesion of cells within emboli. E-cadherin overexpression is present in IBC models such as SUM149 and Mary-X, and constitutes part of a defined IBC molecular signature [36,87-91].

Overexpression of E-cadherin in IBC is seen in lymphovascular tumor emboli and in infiltrating tumor cells and seems to be involved in a metastatic process in which cohesion of cell clusters increases metastasis [37].

To confirm E-cadherin overexpression is responsible for the tight junctions inside of clusters, investigators used Mary-X, a human xenograft model of IBC, to show that Ecadherin membrane expression contributes to an oncogenic effect while promoting metastasis 
instead of suppressing it [92]. Specifically they observed the mechanism of E-cadherin overexpression was not transcriptional but instead related to altered protein trafficking. Ecadherin protein levels were 5- to 10-fold higher, but real-time RT-PCR, demonstrated Ecadherin transcript levels in Mary-X were 3- to 11-fold less than in other E-cadherin positive human breast carcinoma lines These observations suggested altered E-cadherin trafficking contributes to its oncogenic rather than suppressive role in IBC.

Cooperation between Sialyl Lewis x/a $\left(\mathrm{sLe}^{\mathrm{x} / \mathrm{a}}\right)$ under-expression and E-cadherin overexpression provided a molecular explanation for the formation of the lymphovascular emboli in the Mary X IBC model. Low $\mathrm{sLe}^{\mathrm{x} / \mathrm{a}}$ expression impedes adherence to the lymphovascular endothelium, and thus allows mobility of cell clusters. At the same time, the lack of electrostatic repulsion between $\mathrm{sLe}^{\mathrm{x} / \mathrm{a}}$ epitopes favors the maintenance of E-cadherin homodimers between cells increasing cellular cohesion [36].

In CIMC cell lines, there has been limited characterization of $s L e^{\mathrm{x} / \mathrm{a}}$ expression, but in the recently established IPC-366 CIMC cell line, E-cadherin and COX-2 overexpression were coupled with high proliferation rates, negative hormone receptors (PR, ER) and HER2 [23]. In humans, COX-2 overexpression has been detected in the IBC cell line SUM149 and, it is suggested to drive celecoxib resistance in this cell line [34].

Finally, in both the MARY-X model and the CMT-U27 canine mammary carcinoma cell line, overexpression of E-cadherin and loss of Sialyl Lewis $x\left(\mathrm{sLe}^{\mathrm{x}}\right)$ were observed in a heterogeneous cell population supporting the existence of interchangeable states of cohesion and repulsion between cells of tumor emboli to promote the metastatic process [91]. Comparative molecular biology aspects of CIMC and IBC are summarized in Table 3 $[22,33,36,84,85,91,93]$. 
Table 3 - The Biology and Molecular Biology of Human Inflammatory Breast Cancer (IBC) and Canine Inflammatory Mammary Carcinoma (CIMC)

\begin{tabular}{|c|c|c|c|}
\hline \multicolumn{4}{|c|}{ The Inflammatory Microenvironment } \\
\hline Property and references & CIMC & IBC & Comment \\
\hline $\begin{array}{l}\text { Cytokines in serum and in } \\
\text { lymph drainage } \\
{[22],[33]}\end{array}$ & $\begin{array}{l}\text { - Higher IL-10 and IL-8 serum levels in } \\
\text { CIMC tumors than in malignant non- } \\
\text { CIMC tumors, mammary-gland } \\
\text { hyperplasia and benign tumors }\end{array}$ & $\begin{array}{l}\text { - Comparing the cytokine profile of the } \\
\text { supernatant of CD14 } 4^{+} \text {cells drained from } \\
\text { axillary tributaries during surgery revealed } \\
\text { significantly higher levels of TNF- } \alpha \text {, } \\
\text { MCP-1/CCL2, IL-10 and IL-8 in IBC as } \\
\text { compared to patients with non-IBC tumors }\end{array}$ & $\begin{array}{l}\text { - Highlights the importance of } \\
\text { macrophage infiltration in IBC } \\
\text { and how secreted cytokines may } \\
\text { contribute to migration and } \\
\text { invasion }\end{array}$ \\
\hline $\begin{array}{l}\text { Cytokines in tissues } \\
\text { [33] }\end{array}$ & $\begin{array}{l}\text { - In tumor-tissue homogenates, only IL-10 } \\
\text { was significantly higher in CIMC than in } \\
\text { malignant non-CIMC tumors, mammary- } \\
\text { gland hyperplasia and benign tumors }\end{array}$ & $\begin{array}{l}\text { - Immunohistochemistry to detect tumor- } \\
\text { associated CD } 14^{+} \text {cells found higher levels } \\
\text { in IBC than in non-IBC }\end{array}$ & $\begin{array}{l}\text { - Results suggest a role for } \\
\text { immunosuppression in the } \\
\text { progression of CIMC }\end{array}$ \\
\hline $\begin{array}{l}\text { Cell lines } \\
{[33,84]}\end{array}$ & - No cell line studies & $\begin{array}{l}\text { - In vitro treatment with recombinant TNF- } \\
\alpha, \text { IL-10 or IL- } 8 \text { significantly increased } \\
\text { motility and invasion of IBC cancer cell } \\
\text { lines } \\
\text { - Treatment with media conditioned by T- } \\
\text { cells or PBMCs rich in TNF- } \alpha \text {, IL- } 6 \text { and } \\
\text { TGF- } \beta \text { induced EMT transition in four } \\
\text { IBC cell lines SUM-149, SUM-190, IBC-3 } \\
\text { and KPL-4 }\end{array}$ & $\begin{array}{l}\text { - Results suggest secreted } \\
\text { cytokines may contribute to } \\
\text { migration and invasion } \\
\text { - Interpretation limited by lack of } \\
\text { in vivo data, where cohesive E- } \\
\text { cadherin overexpressing emboli } \\
\text { form and where the role of EMT } \\
\text { in IBC metastasis may not be as } \\
\text { prominent }\end{array}$ \\
\hline \multicolumn{4}{|c|}{ Epithelial to Mesenchymal Transition (EMT) } \\
\hline $\begin{array}{l}\text { TGF } \beta \\
{[36,60,85,91,93]}\end{array}$ & $\begin{array}{l}\text { - In CMT-U27 canine mammary } \\
\text { carcinoma cells, overexpression of E- } \\
\text { cadherin and loss of Sialyl Lewis x } \\
\left(\text { sLe }^{\mathrm{x}}\right) \text { were observed in a heterogeneous } \\
\text { cell population supporting the existence } \\
\text { of interchangeable states of cohesion and } \\
\text { repulsion between cells of tumor emboli } \\
\text { to promote the metastatic process }\end{array}$ & $\begin{array}{l}\text { - TGF- } \beta \text { activates transcription factors } \\
\text { regulating EMT including SMAD. } \\
\text { However TGF } \beta \text { and SMAD expression are } \\
\text { reduced in IBC versus non-IBC samples } \\
\text { - Expression of E-cadherin and the } \\
\text { mechanisms involved in the cohesion of } \\
\text { cells have been found in tumor emboli } \\
\text { - In the Mary-X cell line expression of E- } \\
\left.\text { cadherin and loss of Sialyl Lewis x (sLe }{ }^{\mathrm{x}}\right) \\
\text { contribute to metastasis }\end{array}$ & $\begin{array}{l}\text { - Interchangeable states of } \\
\text { cohesion (E-cadherin) and } \\
\text { repulsion [loss of Sialyl Lewis } \mathrm{x} \\
\left(\mathrm{sLe}^{\mathrm{x}}\right) \text { ] between cells of tumor } \\
\text { emboli can promote the } \\
\text { metastatic process }\end{array}$ \\
\hline
\end{tabular}

Abbreviations: CIMC, canine inflammatory mammary cancer; IBC, inflammatory breast cancer; EMT, epithelial to mesenchymal transition; TNFa, tumor necrosis factor alpha 


\section{Clinical Presentation and Pathologic/Histologic Findings}

In humans, IBC is a clinical diagnosis characterized by a rapid enlargement of the breast, changes in the overlying skin, with early erythematous discoloration and an orangepeel appearance due to dermal edema (peau d'orange) with or without underlying discrete or palpable masses [46] (Figures 1A, B, C). These signs often cause misdiagnosis of an inflammatory or infectious process [27]. As in human IBC, the clinical presentation of CIMC can be wrongly diagnosed as mastitis or dermatitis due to extensive inflammation of the skin overlying the mammary glands, edema, as well as the pain involving the the axillary, mammary and inguinal regions (Figure 1D, E, F). Signs of generalized weakness, anorexia and metastasis have also been reported as significantly more frequent in CIMC than in other mammary tumor types [16].

In humans, primary IBC develops de novo in a previously normal breast (Figure 1B); while secondary IBC is characterized by a distinct presentation of the disease, with a diffuse chest wall rash or nodules that may quickly form ulcers (Figure 1A and C). This form of IBC can be present in patients with a history of non-inflammatory disease in the chest wall [27]. Another presentation of IBC, termed clinically occult, is described by the absence of clinical signs of inflammation in patients with aggressive breast cancer with histologically confirmed invasion of the dermal lymphatics by tumor emboli [94]. As in humans with a diagnosis of IBC, two clinical forms of CIMC have been described in companion dogs. Primary CIMC develops without a previous history of mammary nodules, while secondary CIMC occurs after a diagnosis of a mammary tumor, generally forming at the surgical wound site [16]. Two histological patterns of neoplastic dermal infiltration - tubular/papillary and sarcomatous-like - have been observed in CIMC [19]. Finally, histological types might differ, but are generally diagnosed as locally advanced invasive carcinoma of the breast in humans or as anaplastic carcinomas in dogs.

In both species, the histological hallmark of inflammatory carcinomas is the formation of tumor emboli in dermal lymphatics resulting in profuse edema due to the obstruction of lymph drainage (Figure 2A and B). While emboli are characteristic of IBC, they are not specific [95]. For a correct diagnosis of inflammatory carcinoma, the histopathological diagnosis must be combined with the observation of clinical signs related to exuberant inflammation - tenderness, redness, edema, warmth, firmness [20,28] Dermal emboli in IBC patients are generally numerous and larger than in patients with non-IBC even though these characteristics present no correlation with the degree of breast-skin redness [5]. 
In a retrospective study of Algerian IBC patients, $77 \%$ presented dermal emboli, although the presence of tumor emboli was not associated with lymph node metastasis or overall survival [63]. However, the presence of tumor emboli, in $70 \%$ of IBC cases ( $25 \%$ local IBC, $45 \%$ diffuse IBC; $\mathrm{P}=.01$ ), was associated with diffuse presentation and 3-fold higher risk of relapse in a study of French-Tunisian IBC patients [96].

Finally, mild to moderate lymphoplasmocytic infiltration may be noted around some of the lymphovascular perivascular space [20,27]. Recent data have shown statistically significant increases in tumor-infiltrating lymphocytes in IBC patients, relative to non-IBC, and associations with TNBC status and pathologic complete response to neoadjuvant chemotherapy $[97,98]$

Vasculogenic mimicry, the formation of vascular channels lined by tumor cells mimicking endothelial cells, is another characteristic identified in both IBC and CIMC $[99,100]$, and it seems to reflect the exuberant angiogenic events taking place. In WIBC-9 xenografts, a model of human IBC, vasculogenic mimicry, induced by angiogenic factors, was identified in hypoxic areas at the center of the tumors where vascular channels form independently of endothelial cells[99]. Studies have highlighted the intensive lymphangiogenesis and angiogenesis, contributing to the high metastatic potential of IBC [17,37,51,101] and CIMC [19,102,103]. To illustrate this, expression of CD31, an endothelial cell marker used to evaluate microvessel density as a measurement of neoangiogenesis, is shown for both IMC and CIMC in Figure 2, C and D respectively. A summary of comparative clinical signs, histologic and pathologic findings in CIMC and IBC is presented in Table 4 [17,19,20,27,37,51,94,99-103] 
Table 4: Clinical Presentation and Pathologic/Histologic Findings

\begin{tabular}{|c|c|c|}
\hline Variable & CIMC & IBC \\
\hline Clinical diagnosis & $\begin{array}{l}\text { - Rapid painful enlargement of breast } \\
\text { - Early erythematous discoloration and an orange- } \\
\text { peel appearance due to the dermal edema (peau } \\
\text { d'orange) } \\
\text { - With or without underlying discrete or palpable } \\
\text { masses }\end{array}$ & $\begin{array}{l}\text { - Inflammation that can be wrongly diagnosed as mastitis or } \\
\text { dermatitis due to extensive inflammation of the skin } \\
\text { overlying the mammary glands } \\
\text { - Edema } \\
\text { - Suggestion of increased sensitivity over the axillary, } \\
\text { mammary and inguinal regions }\end{array}$ \\
\hline Clinical history & $\begin{array}{l}\text { - Primary CIMC: Develops without a previous } \\
\text { history of mammary nodules } \\
\text { - Secondary CIMC: Occurs after a diagnosis of a } \\
\text { mammary tumor, generally forming at the } \\
\text { surgical wound }\end{array}$ & $\begin{array}{l}\text { - Primary IBC: Develops de novo in a previously normal } \\
\text { breast } \\
\text { - Secondary IBC: Characterized by diffuse chest wall rash or } \\
\text { nodules that may quickly form ulcers [27] } \\
\text { - A clinically occult presentation can occur with absence of } \\
\text { clinical signs of inflammation in patients with aggressive } \\
\text { breast cancer with histologically confirmed invasion of the } \\
\text { dermal lymphatics by tumor emboli [94] }\end{array}$ \\
\hline $\begin{array}{l}\text { Histology - Tumor emboli in dermal } \\
\text { lymphatics }\end{array}$ & \multicolumn{2}{|c|}{$\begin{array}{l}\text { - In both species, the histological hallmark is tumor emboli in dermal lymphatics leading to edema due to lymphatic } \\
\text { obstruction. Lymphoplasmocytic infiltration may be seen in some lymphovascular/perivascular spaces }[20,27]\end{array}$} \\
\hline Histology - Vasculogenic mimicry & \multicolumn{2}{|c|}{$\begin{array}{l}\text { - Vasculogenic mimicry (formation of vascular channels with tumor cells mimicking endothelial cells) seen in both } \\
\text { IBC and CIMC }[99,100]\end{array}$} \\
\hline $\begin{array}{l}\text { Histology - Lymphangiogenesis and } \\
\text { angiogenesis }\end{array}$ & \multicolumn{2}{|c|}{ - Intensive and contribute to the high metastatic potential of IBC $[17,37,51,101]$ and CIMC $[19,102,103]$} \\
\hline Histology - Immune infiltrates & - Not yet reported & $\begin{array}{l}\text { - Recent data have shown statistically significant increases in } \\
\text { tumor-infiltrating lymphocytes in IBC patients }\end{array}$ \\
\hline
\end{tabular}




\section{Clinical management}

\subsection{Standard of care treatment}

Currently, for patients diagnosed with IBC, a multidisciplinary treatment involves (1) neoadjuvant systemic therapy with a taxane plus anthracycline chemotherapy adding a HER2 targeted therapy for HER + tumors; (2) followed by total mastectomy with level 1/11 axillary dissection; and (3) adjuvant radiation therapy to the chest wall and draining lymphatics; with (4) possible delayed breast reconstruction and (5) completion of chemotherapy if not completed pre-operatively with endocrine therapy if either ER or PR positive and possible continuation of HER2-directed therapy [45]. Alternative therapeutic options have been suggested, including preoperative primary systemic chemotherapies with a docetaxel-epirubicin protocol with curative intent, which was demonstrated to lead to equivalent outcomes as anthracycline-containing protocols [104]. A 20-year follow-up study has also evaluated the possibility of combining only chemotherapy plus hormonal therapy and radiation in cases of nonmetastatic IBC, maintaining survival rates comparable to the standard-of-care treatment [105].

The preferred treatment option for CMT is the surgical excision of the mammary glands [26]. However, for CIMC, as with invasive mammary carcinomas, neoadjuvant chemotherapy and/or palliative treatments might be preferable. Due to the diffuse presentation of CIMC and extensive inflammation, with difficult definition of surgical margins, incomplete excision is a risk too frequently taken [106].

There is no consensus for a neoadjuvant chemotherapy protocol for CIMC. One clinical study revealed a clinical benefit on the prognosis of dogs with CIMC treated with piroxicam, a nonselective COX-2 inhibitor, alone or in combination with other chemotherapeutic drugs such as carboplatin, doxorubicin, capecitabine or cisplatin [6]. A positive response to piroxicam treatment was also observed in a group of 7 dogs with CIMC, in which the CIMC-associated clinical signs were visibly reduced and survival times increased relative to doxorubicin-treated animals [107]. Another study explored the effect on the overall survival time in dogs undergoing palliative treatment with piroxicam and antibiotics versus a combination of palliative and chemotherapeutic treatments combining mitoxantrone, vincristine and cyclophosphamide intravenously or giving mitoxantrone alone. No statistically significant differences were observed between the two groups, although dogs given chemotherapeutic treatment had longer mean survival times (57 days) than dogs on palliative treatment (32 days) [108]. However, large-scale clinical trials are needed to validate these different modalities and establish guidelines for recommended therapeutic approaches 
for CIMC. Despite short overall survival, improved quality of life and slightly slower disease progression were observed with metronomic chemotherapy protocols using chlorambucil and firocoxib (a selective COX-2 inhibitor) [109].

\subsection{Targeted therapies}

Targeted treatments in humans have included both small molecule inhibitors and monoclonal antibody therapies. As an example, neoadjuvant anti-VEGF monoclonal antibody therapy with bevacizumab has been explored in combination with trastuzumab in the treatment for HER2-positive IBCs [110]. The preliminary results of a phase 2 clinical trial of primary IBC, that administered chemotherapy and radiotherapy with neoadjuvant bevacizumab plus trastuzumab, has demonstrated good tolerability and efficacy with $98 \%$ of patients achieving a clinical response with regression of inflammatory clinical signs associated with IBC [47].

Additionally, due to expression of EGFR in nearly $30 \%$ of IBC cases and its association with a poor outcome [111], panitumumab, a fully human monoclonal antibody targeting EGFR is under evaluation in a phase II trial among patients with a diagnosis of IBC patients (NCT01036087). Accrual began in 2010 and at the end of 2017 final results were still not yet available underscoring the difficulty recruiting such a select group of patients.

New therapeutic targets have been suggested arising from observations of IBC cell lines and tumor samples obtained from patients. Altered copy numbers of the anaplastic lymphoma kinase (ALK) gene have been detected in IBCs , and the susceptibility to crizotinib, an ALK and ROS1 inhibitor, was proven using mice bearing IBC xenografts. In the MaryX model Crizotinib induced apoptosis and reduced ALK expression [112]. The efficacy of this regimen in IBC will need to be explored.. Other potential therapeutic targets currently under preclinical investigation in IBC are E-cadherin and RhoC GTPase, therapies that ideally would be integrated in large-scale, multicenter cohort studies [5]. However, positive preclinical evaluations in cell lines and rodent models are often difficult to translate into positive clinical benefit in patients. This suggests that a more appropriate model system, such as dogs with CIMC, may be valuable as a more predictive preclinical model.

To our knowledge there are no targeted therapies available for dogs with CIMC, albeit this reality could be transformed in coming years with the development of personalized antibody therapy for canine patients. Recent data showing an acceptabel safety profile with the anti-PD1 and PD-L1 monoclonal antibody-therapy used in humans with very limited activity in heavily pretreated advanced, triple-negative breast cancer $[113,114]$,offers dogs as 
a possible model for evaluating immunotherapy combinations with hopefully greater activity [115]. Preliminary studies assessing PD-L1 and PD1 expression in a wide range of canine malignancies, has found PD-L1 positivity in malignant CMT among others, suggesting assessment of the PD-1/PD-L1 axis as a therapeutic target can be pursued, particularly for canine oral melanoma where PD1 expressing T-cells were also observed. [116,117]. Following the recent trend in human cancer immunotherapy, most therapeutic monoclonal antibodies in veterinary oncology remain under investigation and pre-clinical development [118]. Presently, the FDA has only licensed anti-CD20 and CD52 chimeric monoclonal antibodies for treatment of canine B and T-cell lymphomas, respectively[119]. Progress toward improved therapeutic options for CIMC will require clinical studies able to test combination protocols and novel therapeutic targets. A summary of the clinical management options for CIMC and IBC is presented in Table 5 [6,26,45,47,106,110-112]

\begin{tabular}{|c|c|c|}
\hline Intervention & CIMC & IBC \\
\hline Standard treatment of care & $\begin{array}{l}\text { - Surgical excision of affected } \\
\text { mammary glands, except on } \\
\text { diffuse presentation }[26,106] \\
\text { - No consensus on } \\
\text { neoadjuvant therapy. Use of } \\
\text { COX-2 inhibitors alone or in } \\
\text { combination with chemotherapy } \\
\text { has been reported[6,110-112] }\end{array}$ & $\begin{array}{l}\text { - Multidisciplinary treatment with } \\
\text { taxane-anthracycline-based } \\
\text { neoadjuvant chemotherapy, followed } \\
\text { by modified radical mastectomy and } \\
\text { adjuvant radiation therapy to the } \\
\text { chest wall and draining lymphatics } \\
\text { [45] }\end{array}$ \\
\hline Targeted therapies & $\begin{array}{l}\text { - Research and development } \\
\text { of targeted therapies for CIMC is } \\
\text { still ongoing. }\end{array}$ & $\begin{array}{l}-\quad \text { Neoadjuvant anti-VEGF } \\
\text { (bevacizumab) plus trastuzumab in } \\
\text { HER2-positive cases [47,110] } \\
\text { - Anti-EGFR (panitumumab) } \\
\text { under evaluation in clinical trial } \\
\text { (NCT01036087). }\end{array}$ \\
\hline
\end{tabular}




\section{Prognostic factors}

Despite the increased understanding of IBC and the multidisciplinary therapeutic approach, women diagnosed with IBC continue to have mortality rates that are higher than those women with non-inflammatory locally advanced breast cancer $[5,111,120]$. Similarly, the prognosis for dogs with CIMC remains poor and overall survival times range between weeks to only a few months $[6,16]$. Dogs receiving chemotherapeuty plus and a non-selective COX-2 inhibitor have shown significantly increased survival times relative to dogs receiving only palliative treatment [6]. However, large-scale clinical trials are warranted to confirm these findings in CIMC. A summary of the prognostic factors in IBC and suggested biomarkers warranting prognostic studies in CIMC is presented on table 6. Prognostic studies in dogs with CIMC are challenging due to the fact that most animals will eventually be euthanized given the severity of the clinical signs presented, instead of dying from advanced metastatic disease.

\subsection{Endocrine and HER2 receptors, chemokine receptors and epidermal growth factors}

In many cases of IBC, the triple-negative status drastically limits the treatment options and impacts negatively impacts patient prognosis [48]. In a retrospective study analyzing of 2,014 women diagnosed with IBC, hormone receptor (ER, PR) positive status was found to be associated with improved overall survival and breast cancer-specific survival $(\mathrm{N}=626 ; \mathrm{HR}=0.55,95 \% \mathrm{CI}=0.47-0.65 ; \mathrm{P}<.05)$ whereas HER2-positive status $(\mathrm{N}=703$; $\mathrm{HR}=0.82,95 \% \mathrm{CI}=0.68$ to $0.99, \mathrm{NS}$ ) was not [125]. Other authors have confirmed the lack of prognostic value of HER2 receptor in IBC [121,122]. However, in patients with HER2positive tumors, treatment with trastuzumab confers benefit and improved survival times compared to HER2-negative patients [121]. It is possible that other molecules in IBC, such as E-cadherin [92,123], RhoC GTPase and WISP3 [39,124,125] may have a greater role in the mechanisms of IBC metastatic invasion, angiogenesis and tumor growth than the HER2 receptor and that targeting these molecules could have a greater impact on the prognosis.

Expression of the chemokine receptors CCR7 and CXCR4, previously associated with breast cancer metastasis [126] has been characterized in IBC. In one study, 40.9\% and $23 \%$ of IBC cases had expression of CXCR4 and CCR7, respectively.. However, only concurrent expression levels of CXCR4 and CCR7 was associated with a trend for shorter overall survival, and this did not reach statistical significance [50].

EGFR pathway activity, defined as the aggregate expression of a group of genes linked to EGFR signaling, is significantly lower in IBC patients who achieve a complete 
pathological response than in those with residual disease after neoadjuvant, anthracyclinebased chemotherapy ( $\mathrm{P}=.02)$ [93]. In CIMC, EGFR protein expression is high in tumor tissue homogenates and significantly increased relative to malignant CMT, benign CMT and nonneoplastic mammary gland $(\mathrm{P}<.001)$. Therefore, incremental EGFR expression is proposed to have a role in the development of CIMC, but this hypothesis needs to be investigated mechanistically [127]. Representative EGFR expression in IBC and CIMC cases is shown on Figure $2 \mathrm{G}$ and $\mathrm{H}$, respectively.

\subsection{Cyclooxygenase-2}

The cyclooxygenase-2 (COX2)/prostaglandin E2 pathway is widely recognized for its role in driving mammary carcinogenesis as an inflammatory mediator and as a promoter of angiogenesis, metastasis and invasion in rodent models of mammary carcinogenesis $[128,129]$. In IBC, however, COX-2 expression and its prognostic value have been understudied. In vitro experiments have shown higher COX-2 expression in cancer stem cell tumorspheres of the IBC cell line SUM149 relative to the non-IBC cell line MCF-7, suggesting a role for COX-2 in stem cell formation and possibly a role in the inflammatory microenvironment of IBC [130]. In CIMC, high levels of COX-2 have been found relative to non-CIMC tumors [18]. There is a positive association of COX-2 with high VEGF-D and VEGFR levels, and the lymphatic proliferation index, supporting the involvement of COX-2 in the lymphangiogenic mechanisms of CIMC [131]. Illustrative expression of COX-2 in IBC and CIMC is shown in Figure 2, images $\mathrm{E}$ and $\mathrm{F}$ respectively.

\subsection{Vascular endothelial growth factor}

Because IBC and CIMC require high levels of angiogenesis as part of their rapidly growing and invasive phenotype [37,101], it was expected that the expression of vascular endothelial growth factor (VEGF-A) is expected to be high. Interestingly, high expression of VEGF-A was found but this was noted in the stromal, but not in the epithelial cells of the tumor, and this was associated with poor disease-free and breast cancer-specific survival in patients with a diagnosis of IBC [51]. In CIMC, augmented tumoral VEGF expression has been reported, but its prognostic value has not been evaluated [102,131,132].

\subsection{Other prognostic factors}

More recently, innovative techniques have been applied to allow earlier prediction of metastatic risk in IBC patients. One study explored the predictive value of microscopic image 
analysis of histopathology sections at the time of diagnosis [133]. By applying the GrayLevel Co-Occurrence Matrix (GLCM) method, parameters of tissue heterogeneity, such as entropy and contrast, were able to predict metastasis outcome more efficiently than commonly used clinical variables. This technique could help to prioritize and select patients with higher metastatic risk for targeted therapies.

Additionally, the number of circulating tumor cells (CTCs) $(\geq 1)$ in patients with stage III IBC patients has also been identified as a good predictor of recurrence after primary systemic therapy, modified radical mastectomy, postoperative radiotherapy and trastuzumab neoadjuvant treatment for HER2 ${ }^{+}$patients [134]. If further confirmed, CTCs could be used to select patients at high risk of relapse. While the presence and prognostic role of CTCs in CIMC is unknown, the findings in humans with IBC warrant studies in CIMC.

\begin{tabular}{|c|c|c|}
\hline \multicolumn{3}{|l|}{ Table 6 - Prognostic factors } \\
\hline & CIMC & IBC \\
\hline Endocrine and HER2 receptors & $\bullet$ & $\begin{array}{l}\text { - } \mathrm{ER}^{+} \mathrm{PR}^{+} \text {cases have improved } \\
\text { outcomes, but not HER2 }{ }^{+} \\
{[125]}\end{array}$ \\
\hline Chemokine receptors & $\bullet$ & $\begin{array}{l}\text { - Concurrent CXCR4 and } \\
\text { CCR7 expression associated } \\
\text { with trend in shorter OS [50]. }\end{array}$ \\
\hline Epidermal growth factor (EGFR) & $\begin{array}{l}\text { - } \quad \text { Role for EGFR in CIMC } \\
\text { progression has been suggested } \\
\text { but prognostic studies are } \\
\text { warranted [127] }\end{array}$ & $\begin{array}{l}\text { - EGFR pathway activity is } \\
\text { lower in patients with } \\
\text { complete pathological } \\
\text { response [93] }\end{array}$ \\
\hline Cyclooxygenase-2 (COX-2) & $\begin{array}{l}\bullet \quad \text { COX-2 associated with } \\
\text { VEGFR levels, and the lymphatic } \\
\text { proliferation index, supporting the } \\
\text { involvement of COX-2 in the } \\
\text { lymphangiogenic mechanisms of } \\
\text { CIMC [131]. Prognostic studies } \\
\text { are warranted }\end{array}$ & $\begin{array}{l}\text { - Prognostic studies are } \\
\text { warranted }\end{array}$ \\
\hline VEGF & $\begin{array}{l}\bullet \quad \text { Tumoral VEGF is expressed } \\
\text { in CIMC but prognostic value has } \\
\text { not been assessed }[102,131,132]\end{array}$ & $\begin{array}{l}\text { Stromal VEGF-A associated } \\
\text { with poor DFS and BCSS } \\
{[51]}\end{array}$ \\
\hline Others & & $\begin{array}{l}\text { Entropy, contrast and other } \\
\text { parameters of tissue } \\
\text { heterogeneity can predict } \\
\text { metastasis[133]. } \\
\text { - } \mathrm{CTCs} \geq 1 \text { predicts recurrence } \\
\text { in HER } 2^{+} \text {IBC patients after } \\
\text { multimodal therapy [134] }\end{array}$ \\
\hline
\end{tabular}

OS - overall survival, DFS - disease free survival, BCSS - breast cancer specific survival, CTCs Circulating tumor cells 


\section{Conclusion and future perspectives (5-year horizon)}

For both humans and dogs, the aggressiveness and lethality of IBC and CIMC, compared to other breast cancer types demands a concerted multidisciplinary effort to identify novel and specific therapeutic options and prognostic factors to help categorize patients and provide better treatments. The fundamental similarities between human IBC and CIMC underlie the value of comparative and translational research for the benefit of both species. Advances in understanding the pathogenesis of both diseases and the development of genome-based molecular and immunological reagents, as well as commercially available high-throughput methodologies such as next-generation sequencing or multiple-cytokine array assays specific for dogs, will enhance our ability to deeply interrogate canine cancers and characterize shared and novel targets for novel therapeutic interventions.

A major challenge of therapeutic development in oncology is the design of clinical trials, often based solely on previous research using rodent models. We would argue CIMC could serve as an intermediate preclinical model between rodent models and humans prior to the design and execution of clinical trials. A canine preclinical model could enable a better understanding of the mechanism of action of a novel intervention, dosing, administration and could potentially improve clinical trial design and hopefully increase success rates while reducing expense. Furthermore, the development of therapies in canines would also serve the animal patients and their owners. Current therapies for canine cancers, as noted above for CIMC, are often not a cost-effective option. The opportunity to perform well-designed and innovative therapy trials at minimal expense for dog owners and researchers would provide canine patients and their owners access to the best therapeutic options while also contributing to improvement in the therapy of human cancer. Additional advantages to using a spontaneous canine model in preclinical studies include the short lifespan after diagnosis that offers the opportunity to accelerate endpoints of clinical trials and the exposure to environmental pollutants that renders dogs as suitable sentinels. While not advocated as a replacement for toxicokinetic studies in rodent models, comparative oncology studies performed in dogs have the potential to provide information not easily obtained by conventional preclinical models prior to human trials [2]. Finally, the existence of CIMC cell lines might facilitate in vitro screening of new therapeutic drugs in preclinical studies for CIMC [23],providing another strategy to further reduce the time and cost of preclinical development. Although testing of novel CIMC therapies can begin immediately, CIMC as a model for IBC could be further optimized with additional comparative studies evaluating immunohistochemical expression of prognostic markers and gene expression profiles. 
We envision that immunotherapeutic strategies will start to be employed for the treatment of canine cancers, including CIMC. In these animals, genetically variable tumors develop spontaneously in a syngeneic environment and in the presence of an intact immune system in an aging animal, thus making dogs diagnosed with CIMC ideal models to research new treatments for this highly metastatic and deadly tumor. Upcoming production of novel therapeutic monoclonal antibodies against biomarkers with prognostic significance could rapidly provide dogs with state-of-the-art therapy and, in parallel, generate clinically relevant new data with direct applicability to subsequent human clinical trial studies.

Given the highly metastatic nature of IBC and CIMC, knowledge obtained about this cancer type could be applied to the management of other highly aggressive epithelial cancer types. In addition, the discovery of new therapeutic targets may provide new opportunities for the treatment of this aggressive disease in both humans and canines. Prospectively, further research is warranted for a better understanding of the biology of IBC and CIMC by identification of specific molecular determinants and the subsequent innovative design of targeted therapies that could halt the metastatic process and hopefully improve outcomes for patients with both IBC and CIMC.

Acknowledgements and Funding information: To develop this work, Teresa P. Raposo was the recipient of a PhD Scholarship grant (SFRH/BD/79158/2011) from the Foundation for Science and Technology (FCT), Ministry of Science and Education, Portugal. This work was also supported by the Operational Competitiveness and Internationalization Program (FEDER/COMPETE/POCI) awarded by European Investment Funds under Project POCI-010145-FEDER-006958 and by national funds from the FCT, under the project UID/AGR/04033/2013.

\section{Reference List}

[1] Gardner HL, Fenger JM, London CA. Dogs as a Model for Cancer. Annu Rev Anim Biosci 2016 Feb $15 ; 4: 199-222$

[2] LeBlanc AK, Mazcko CN, Khanna C. Defining the Value of a Comparative Approach to Cancer Drug Development. Clin Cancer Res 2015 Dec 28;22(9):2133-8.

[3] Pinho SS, Carvalho S, Cabral J, Reis CA, Gartner F. Canine tumors: a spontaneous animal model of human carcinogenesis. Transl Res 2012 Mar;159(3):165-72.

[4] Queiroga FL, Raposo T, Carvalho MI, Prada J, Pires I. Canine mammary tumours as a model to study human breast cancer: most recent findings. In Vivo 2011 May;25(3):455-65.

[5] Yamauchi H, Woodward WA, Valero V, Alvarez RH, Lucci A, Buchholz TA, et al. Inflammatory breast cancer: what we know and what we need to learn. Oncologist 2012;17(7):891-9.

[6] Marconato L, Romanelli G, Stefanello D, Giacoboni C, Bonfanti U, Bettini G, et al. Prognostic factors for dogs with mammary inflammatory carcinoma: 43 cases (2003-2008). J Am Vet Med Assoc 2009 Oct 15;235(8):967-72.

[7] Bell C. A System of Operative Surgery. Hale and Hosmer; 1814. 
[8] Lee B, Tannenbaum N. Inflammatory carcinoma of the breast: A report of twenty-eight cases from the breast clinic of Memorial Hospital. Surg Gynecol Obstet 1924;39:580-95.

[9] Hance KW, Anderson WF, Devesa SS, Young HA, Levine PH. Trends in inflammatory breast carcinoma incidence and survival: the surveillance, epidemiology, and end results program at the National Cancer Institute. J Natl Cancer Inst 2005 Jul 6;97(13):966-75.

[10] Boussen H, Bouzaiene H, Ben HJ, Dhiab T, Khomsi F, Benna F, et al. Inflammatory breast cancer in Tunisia: epidemiological and clinical trends. Cancer 2010 Jun 1;116(11 Suppl):2730-5.

[11] Soliman AS, Banerjee M, Lo AC, Ismail K, Hablas A, Seifeldin IA, et al. High proportion of inflammatory breast cancer in the Population-based Cancer Registry of Gharbiah, Egypt. Breast J 2009 Jul;15(4):432-4.

[12] Levine PH, Veneroso C. The epidemiology of inflammatory breast cancer. Semin Oncol 2008 Feb;35(1):11-6.

[13] Hirko KA, Soliman AS, Banerjee M, Ruterbusch J, Harford JB, Merajver SD, et al. A comparison of criteria to identify inflammatory breast cancer cases from medical records and the Surveillance, Epidemiology and End Results data base, 2007-2009. Breast J 2014 Mar;20(2):185-91.

[14] Susaneck S, Allen T, Hoopes J, Withrow S, Macy D. Inflammatory mammary carcinoma in the dog. J Am An Hosp Assoc 1983;19:971-6.

[15] Perez-Alenza MD, Jimenez A, Nieto AI, Pena L. First description of feline inflammatory mammary carcinoma: clinicopathological and immunohistochemical characteristics of three cases. Breast Cancer Res 2004;6(4):R300-R307.

[16] Perez Alenza MD, Tabanera E, Pena L. Inflammatory mammary carcinoma in dogs: 33 cases (19951999). J Am Vet Med Assoc 2001 Oct 15;219(8):1110-4.

[17] Vermeulen PB, van Golen KL, Dirix LY. Angiogenesis, lymphangiogenesis, growth pattern, and tumor emboli in inflammatory breast cancer: a review of the current knowledge. Cancer 2010 Jun 1;116(11 Suppl):2748-54.

[18] Queiroga FL, Perez-Alenza MD, Silvan G, Pena L, Lopes C, Illera JC. Cox-2 levels in canine mammary tumors, including inflammatory mammary carcinoma: clinicopathological features and prognostic significance. Anticancer Res 2005 Nov;25(6B):4269-75.

[19] Pena L, Perez-Alenza MD, Rodriguez-Bertos A, Nieto A. Canine inflammatory mammary carcinoma: histopathology, immunohistochemistry and clinical implications of 21 cases. Breast Cancer Res Treat 2003 Mar;78(2):141-8.

[20] Goldschmidt M, Pena L, Rasotto R, Zappulli V. Classification and grading of canine mammary tumors. Vet Pathol 2011 Jan;48(1):117-31.

[21] Hsu WL, Lin HY, Chiou SS, Chang CC, Wang SP, Lin KH, et al. Mouse mammary tumor virus-like nucleotide sequences in canine and feline mammary tumors. J Clin Microbiol 2010 Dec;48(12):435462.

[22] de Andres PJ, Illera JC, Caceres S, Diez L, Perez-Alenza MD, Pena L. Increased levels of interleukins 8 and 10 as findings of canine inflammatory mammary cancer. Vet Immunol Immunopathol 2013 Apr 15;152(3-4):245-51.

[23] Caceres S, Pena L, de Andres PJ, Illera MJ, Lopez MS, Woodward WA, et al. Establishment and characterization of a new cell line of canine inflammatory mammary cancer: IPC-366. PLoS One 2015;10(3):e0122277.

[24] Raposo TP, Pires I, Prada J, Queiroga FL, Argyle DJ. Exploring new biomarkers in the tumour microenvironment of canine inflammatory mammary tumours. Vet Comp Oncol 2016 Jan 17.

[25] Raposo TP, Beirao BC, Pires I, Prada J, Brilhante P, Argyle DJ, et al. Immunohistochemical Expression of CCR2, CSF1R and MMP9 in Canine Inflammatory Mammary Carcinomas. Anticancer Res 2016 Apr;36(4):1805-13.

[26] Sorenmo K. Canine mammary gland tumors. Vet Clin North Am Small Anim Pract 2003 May;33(3):573-96.

[27] Robertson FM, Bondy M, Yang W, Yamauchi H, Wiggins S, Kamrudin S, et al. Inflammatory breast cancer: the disease, the biology, the treatment. CA Cancer J Clin 2010 Nov;60(6):351-75.

[28] Edge S, Byrd D, Compton C. Breast. AJCC Cancer Staging Manual. 7th ed. New York, NY: Springer; 2010. p. 347-76.

[29] El-Shinawi M, Mohamed HT, El-Ghonaimy EA, Tantawy M, Younis A, Schneider RJ, et al. Human cytomegalovirus infection enhances NF-kappaB/p65 signaling in inflammatory breast cancer patients. PLoS One 2013;8(2):e55755.

[30] Herrera-Goepfert R, Vela-Chavez T, Carrillo-Garcia A, Lizano-Soberon M, Amador-Molina A, Onate-Ocana LF, et al. High-risk human papillomavirus (HPV) DNA sequences in metaplastic breast carcinomas of Mexican women. BMC Cancer 2013;13:445. 
[31] Pogo BG, Holland JF, Levine PH. Human mammary tumor virus in inflammatory breast cancer. Cancer 2010 Jun 1;116(11 Suppl):2741-4.

[32] Levine PH, Mesa-Tejada R, Keydar I, Tabbane F, Spiegelman S, Mourali N. Increased incidence of mouse mammary tumor virus-related antigen in Tunisian patients with breast cancer. Int J Cancer 1984 Mar 15;33(3):305-8.

[33] Mohamed MM, El-Ghonaimy EA, Nouh MA, Schneider RJ, Sloane BF, El-Shinawi M. Cytokines secreted by macrophages isolated from tumor microenvironment of inflammatory breast cancer patients possess chemotactic properties. Int J Biochem Cell Biol 2014 Jan;46:138-47.

[34] Singh B, Irving LR, Tai K, Lucci A. Overexpression of COX-2 in celecoxib-resistant breast cancer cell lines. J Surg Res 2010 Oct;163(2):235-43.

[35] Robertson FM, Simeone AM, Mazumdar A, Shah AH, McMurray JS, Ghosh S, et al. Molecular and pharmacological blockade of the EP4 receptor selectively inhibits both proliferation and invasion of human inflammatory breast cancer cells. J Exp Ther Oncol 2008;7(4):299-312.

[36] Alpaugh ML, Tomlinson JS, Ye Y, Barsky SH. Relationship of sialyl-Lewis(x/a) underexpression and E-cadherin overexpression in the lymphovascular embolus of inflammatory breast carcinoma. Am J Pathol 2002 Aug;161(2):619-28.

[37] Colpaert CG, Vermeulen PB, Benoy I, Soubry A, van RF, van BP, et al. Inflammatory breast cancer shows angiogenesis with high endothelial proliferation rate and strong E-cadherin expression. $\mathrm{Br} \mathrm{J}$ Cancer 2003 Mar 10;88(5):718-25.

[38] van Laere S, Van dA, I, Van den Eynden GG, Fox SB, Bianchi F, Harris AL, et al. Distinct molecular signature of inflammatory breast cancer by cDNA microarray analysis. Breast Cancer Res Treat 2005 Oct;93(3):237-46.

[39] Kleer CG, Zhang Y, Pan Q, Gallagher G, Wu M, Wu ZF, et al. WISP3 and RhoC guanosine triphosphatase cooperate in the development of inflammatory breast cancer. Breast Cancer Res 2004;6(2):R110-R115.

[40] Xu XD, Shen HB, Zhu L, Lu JQ, Zhang L, Luo ZY, et al. Anti-RhoC siRNAs inhibit the proliferation and invasiveness of breast cancer cells via modulating the KAI1, MMP9, and CXCR4 expression. Onco Targets Ther 2017;10:1827-34.

[41] Lerebours F, Vacher S, Andrieu C, Espie M, Marty M, Lidereau R, et al. NF-kappa B genes have a major role in inflammatory breast cancer. BMC Cancer 2008;8:41.

[42] Ross JS, Ali SM, Wang K, Khaira D, Palma NA, Chmielecki J, et al. Comprehensive genomic profiling of inflammatory breast cancer cases reveals a high frequency of clinically relevant genomic alterations. Breast Cancer Res Treat 2015 Nov;154(1):155-62.

[43] Silvera D, Arju R, Darvishian F, Levine PH, Zolfaghari L, Goldberg J, et al. Essential role for eIF4GI overexpression in the pathogenesis of inflammatory breast cancer. Nat Cell Biol 2009 Jul;11(7):9038.

[44] Bertucci F, Finetti P, Colpaert C, Mamessier E, Parizel M, Dirix L, et al. PDL1 expression in inflammatory breast cancer is frequent and predicts for the pathological response to chemotherapy. Oncotarget 2015 May 30;6(15):13506-19.

[45] Rueth NM, Lin HY, Bedrosian I, Shaitelman SF, Ueno NT, Shen Y, et al. Underuse of trimodality treatment affects survival for patients with inflammatory breast cancer: an analysis of treatment and survival trends from the National Cancer Database. J Clin Oncol 2014 Jul 1;32(19):2018-24.

[46] Dawood S, Merajver SD, Viens P, Vermeulen PB, Swain SM, Buchholz TA, et al. International expert panel on inflammatory breast cancer: consensus statement for standardized diagnosis and treatment. Ann Oncol 2011 Mar;22(3):515-23.

[47] Pierga JY, Petit T, Delozier T, Ferrero JM, Campone M, Gligorov J, et al. Neoadjuvant bevacizumab, trastuzumab, and chemotherapy for primary inflammatory HER2-positive breast cancer (BEVERLY2): an open-label, single-arm phase 2 study. Lancet Oncol 2012 Apr;13(4):375-84.

[48] Li J, Gonzalez-Angulo AM, Allen PK, Yu TK, Woodward WA, Ueno NT, et al. Triple-negative subtype predicts poor overall survival and high locoregional relapse in inflammatory breast cancer. Oncologist 2011;16(12):1675-83.

[49] Masuda H, Baggerly KA, Wang Y, Iwamoto T, Brewer T, Pusztai L, et al. Comparison of molecular subtype distribution in triple-negative inflammatory and non-inflammatory breast cancers. Breast Cancer Res 2013;15(6):R112.

[50] Cabioglu N, Gong Y, Islam R, Broglio KR, Sneige N, Sahin A, et al. Expression of growth factor and chemokine receptors: new insights in the biology of inflammatory breast cancer. Ann Oncol 2007 Jun;18(6):1021-9.

[51] Arias-Pulido H, Chaher N, Gong Y, Qualls C, Vargas J, Royce M. Tumor stromal vascular endothelial growth factor $\mathrm{A}$ is predictive of poor outcome in inflammatory breast cancer. BMC Cancer 2012;12:298. 
[52] Lerebours F, Cizeron-Clairac G, Susini A, Vacher S, Mouret-Fourme E, Belichard C, et al. miRNA expression profiling of inflammatory breast cancer identifies a 5-miRNA signature predictive of breast tumor aggressiveness. Int J Cancer 2013 Oct 1;133(7):1614-23.

[53] Pena L, Silvan G, Perez-Alenza MD, Nieto A, Illera JC. Steroid hormone profile of canine inflammatory mammary carcinoma: a preliminary study. J Steroid Biochem Mol Biol 2003 Feb;84(23):211-6.

[54] Illera JC, Perez-Alenza MD, Nieto A, Jimenez MA, Silvan G, Dunner S, et al. Steroids and receptors in canine mammary cancer. Steroids 2006 Jul;71(7):541-8.

[55] Sanchez-Archidona AR, Jimenez MA, Perez-Alenza D, Silvan G, Illera JC, Pena L, et al. Steroid pathway and oestrone sulphate production in canine inflammatory mammary carcinoma. J Steroid Biochem Mol Biol 2007 May;104(3-5):93-9.

[56] de Andres PJ, Caceres S, Clemente M, Perez-Alenza MD, Illera JC, Pena L. Profile of Steroid Receptors and Increased Aromatase Immunoexpression in Canine Inflammatory Mammary Cancer as a Potential Therapeutic Target. Reprod Domest Anim 2016 Apr;51(2):269-75.

[57] Pena L, Gama A, Goldschmidt MH, Abadie J, Benazzi C, Castagnaro M, et al. Canine mammary tumors: a review and consensus of standard guidelines on epithelial and myoepithelial phenotype markers, HER2, and hormone receptor assessment using immunohistochemistry. Vet Pathol 2014 Jan;51(1):127-45.

[58] Burrai GP, Tanca A, De Miglio MR, Abbondio M, Pisanu S, Polinas M, et al. Investigation of HER2 expression in canine mammary tumors by antibody-based, transcriptomic and mass spectrometry analysis: is the dog a suitable animal model for human breast cancer? Tumour Biol 2015 Nov;36(11):9083-91.

[59] Matro JM, Li T, Cristofanilli M, Hughes ME, Ottesen RA, Weeks JC, et al. Inflammatory breast cancer management in the national comprehensive cancer network: the disease, recurrence pattern, and outcome. Clin Breast Cancer 2015 Feb;15(1):1-7.

[60] Van Laere SJ, Ueno NT, Finetti P, Vermeulen P, Lucci A, Robertson FM, et al. Uncovering the molecular secrets of inflammatory breast cancer biology: an integrated analysis of three distinct affymetrix gene expression datasets. Clin Cancer Res 2013 Sep 1;19(17):4685-96.

[61] Andrade FH, Figueiroa FC, Bersano PR, Bissacot DZ, Rocha NS. Malignant mammary tumor in female dogs: environmental contaminants. Diagn Pathol 2010;5:45.

[62] Valeron PF, Pestano JJ, Luzardo OP, Zumbado ML, Almeida M, Boada LD. Differential effects exerted on human mammary epithelial cells by environmentally relevant organochlorine pesticides either individually or in combination. Chem Biol Interact 2009 Aug 14;180(3):485-91.

[63] Chaher N, Arias-Pulido H, Terki N, Qualls C, Bouzid K, Verschraegen C, et al. Molecular and epidemiological characteristics of inflammatory breast cancer in Algerian patients. Breast Cancer Res Treat 2012 Jan;131(2):437-44.

[64] Subramanian A, Salhab M, Mokbel K. Oestrogen producing enzymes and mammary carcinogenesis: a review. Breast Cancer Res Treat 2008 Sep;111(2):191-202.

[65] Nakata T, Takashima S, Shiotsu Y, Murakata C, Ishida H, Akinaga S, et al. Role of steroid sulfatase in local formation of estrogen in post-menopausal breast cancer patients. J Steroid Biochem Mol Biol 2003 Sep;86(3-5):455-60.

[66] Bjerregaard-Olesen C, Ghisari M, Kjeldsen LS, Wielsoe M, Bonefeld-Jorgensen EC. Estrone sulfate and dehydroepiandrosterone sulfate: Transactivation of the estrogen and androgen receptor. Steroids 2016 Jan;105:50-8.

[67] Illera JC, Caceres S, Pena L, de Andres PJ, Monsalve B, Illera MJ, et al. Steroid hormone secretion in inflammatory breast cancer cell lines. Horm Mol Biol Clin Investig 2015 Dec;24(3):137-45.

[68] Taher C, de BJ, Mohammad AA, Religa P, Hartman J, Yaiw KC, et al. High prevalence of human cytomegalovirus proteins and nucleic acids in primary breast cancer and metastatic sentinel lymph nodes. PLoS One 2013;8(2):e56795.

[69] Mohamed HT, El-Shinawi M, Nouh MA, Bashtar AR, Elsayed ET, Schneider RJ, et al. Inflammatory breast cancer: high incidence of detection of mixed human cytomegalovirus genotypes associated with disease pathogenesis. Front Oncol 2014;4:246.

[70] El-Shinawi M, Mohamed HT, Abdel-Fattah HH, Ibrahim SA, El-Halawany MS, Nouh MA, et al. Inflammatory and Non-inflammatory Breast Cancer: A Potential Role for Detection of Multiple Viral DNAs in Disease Progression. Ann Surg Oncol 2016 Feb;23(2):494-502.

[71] Sardon D, Blundell R, Burrai GP, Alberti A, Tore G, Passino ES, et al. Absence of canine papillomavirus sequences in canine mammary tumours. J Comp Pathol 2015 Feb;152(2-3):172-6.

[72] Melana SM, Nepomnaschy I, Sakalian M, Abbott A, Hasa J, Holland JF, et al. Characterization of viral particles isolated from primary cultures of human breast cancer cells. Cancer Res 2007 Sep 15;67(18):8960-5. 
[73] Pogo BG, Melana SM, Holland JF, Mandeli JF, Pilotti S, Casalini P, et al. Sequences homologous to the mouse mammary tumor virus env gene in human breast carcinoma correlate with overexpression of laminin receptor. Clin Cancer Res 1999 Aug;5(8):2108-11.

[74] Wang Y, Holland JF, Bleiweiss IJ, Melana S, Liu X, Pelisson I, et al. Detection of mammary tumor virus env gene-like sequences in human breast cancer. Cancer Res 1995 Nov 15;55(22):5173-9.

[75] Brower V. Mouse mammary tumor virus: new tumor virus or just a rumor virus? J Natl Cancer Inst 2009 Mar 4;101(5):293-5.

[76] Park DJ, Southey MC, Giles GG, Hopper JL. No evidence of MMTV-like env sequences in specimens from the Australian Breast Cancer Family Study. Breast Cancer Res Treat 2011 Jan;125(1):229-35.

[77] Zur HH. The search for infectious causes of human cancers: where and why. Virology 2009 Sep 15;392(1):1-10.

[78] Salmons B, Gunzburg WH. Revisiting a role for a mammary tumor retrovirus in human breast cancer. Int J Cancer 2013 Oct 1;133(7):1530-5.

[79] Callahan R, Smith GH. MMTV-induced mammary tumorigenesis: gene discovery, progression to malignancy and cellular pathways. Oncogene 2000 Feb 21;19(8):992-1001.

[80] Salmons B, Lawson JS, Gunzburg WH. Recent developments linking retroviruses to human breast cancer: infectious agent, enemy within or both? J Gen Virol 2014 Dec;95(Pt 12):2589-93.

[81] Hanahan D, Weinberg RA. Hallmarks of cancer: the next generation. Cell 2011 Mar 4;144(5):646-74.

[82] Martin OA, Redon CE, Dickey JS, Nakamura AJ, Bonner WM. Para-inflammation mediates systemic DNA damage in response to tumor growth. Commun Integr Biol 2011 Jan;4(1):78-81.

[83] Colotta F, Allavena P, Sica A, Garlanda C, Mantovani A. Cancer-related inflammation, the seventh hallmark of cancer: links to genetic instability. Carcinogenesis 2009 Jul;30(7):1073-81.

[84] Cohen EN, Gao H, Anfossi S, Mego M, Reddy NG, Debeb B, et al. Inflammation Mediated Metastasis: Immune Induced Epithelial-To-Mesenchymal Transition in Inflammatory Breast Cancer Cells. PLoS One 2015;10(7):e0132710.

[85] Lamouille S, Xu J, Derynck R. Molecular mechanisms of epithelial-mesenchymal transition. Nat Rev Mol Cell Biol 2014 Mar;15(3):178-96.

[86] Bertucci F, Finetti P, Vermeulen P, Van DP, Dirix L, Birnbaum D, et al. Genomic profiling of inflammatory breast cancer: a review. Breast 2014 Oct;23(5):538-45.

[87] Van den Eynden GG, Van dA, I, van LS, Colpaert CG, Van DP, Merajver S, et al. Validation of a tissue microarray to study differential protein expression in inflammatory and non-inflammatory breast cancer. Breast Cancer Res Treat 2004 May;85(1):13-22.

[88] Dong HM, Liu G, Hou YF, Wu J, Lu JS, Luo JM, et al. Dominant-negative E-cadherin inhibits the invasiveness of inflammatory breast cancer cells in vitro. J Cancer Res Clin Oncol 2007 Feb;133(2):83-92.

[89] Charafe-Jauffret E, Tarpin C, Bardou VJ, Bertucci F, Ginestier C, Braud AC, et al. Immunophenotypic analysis of inflammatory breast cancers: identification of an 'inflammatory signature'. J Pathol 2004 Mar;202(3):265-73.

[90] Alpaugh ML, Tomlinson JS, Shao ZM, Barsky SH. A novel human xenograft model of inflammatory breast cancer. Cancer Res 1999 Oct 15;59(20):5079-84.

[91] Pinho SS, Reis CA, Gartner F, Alpaugh ML. Molecular plasticity of E-cadherin and sialyl lewis x expression, in two comparative models of mammary tumorigenesis. PLoS One 2009;4(8):e6636.

[92] Ye Y, Tellez JD, Durazo M, Belcher M, Yearsley K, Barsky SH. E-cadherin accumulation within the lymphovascular embolus of inflammatory breast cancer is due to altered trafficking. Anticancer Res 2010 Oct;30(10):3903-10.

[93] Bertucci F, Ueno NT, Finetti P, Vermeulen P, Lucci A, Robertson FM, et al. Gene expression profiles of inflammatory breast cancer: correlation with response to neoadjuvant chemotherapy and metastasisfree survival. Ann Oncol 2014;25:358-65.

[94] Saltzstein SL. Clinically occult inflammatory carcinoma of the breast. Cancer 1974 Aug;34(2):382-8.

[95] Bonnier P, Charpin C, Lejeune C, Romain S, Tubiana N, Beedassy B, et al. Inflammatory carcinomas of the breast: a clinical, pathological, or a clinical and pathological definition? Int J Cancer 1995 Aug 9;62(4):382-5.

[96] Le MG, Arriagada R, Contesso G, Cammoun M, Pfeiffer F, Tabbane F, et al. Dermal lymphatic emboli in inflammatory and noninflammatory breast cancer: a French-Tunisian joint study in 337 patients. Clin Breast Cancer 2005 Dec;6(5):439-45.

[97] Colpaert CG, Marsan M, Vermeulen P, Dirix L, van Laere S, Inflammatory Breast Cancer International Consortium. Abstract P4-04-20: Tumor infiltrating lymphocytes in inflammatory breast cancer. Cancer Res 2015;75(9). 
[98] Kaufman S, Arias-Pulido H, Colpaert CG, Chaher N, Qualls C, Marotti JD, et al. Abstract P5-08-13: Tumor infiltrating lymphocytes and pathological response are prognostic biomarkers in inflammatory and non-inflammatory breast cancer. 2016.

[99] Shirakawa K, Kobayashi H, Heike Y, Kawamoto S, Brechbiel MW, Kasumi F, et al. Hemodynamics in vasculogenic mimicry and angiogenesis of inflammatory breast cancer xenograft. Cancer Res 2002 Jan 15;62(2):560-6.

[100] Clemente M, Perez-Alenza MD, Illera JC, Pena L. Histological, immunohistological, and ultrastructural description of vasculogenic mimicry in canine mammary cancer. Vet Pathol 2010 Mar;47(2):265-74.

[101] Van der Auwera I, Van Laere SJ, Van den Eynden GG, Benoy I, Van DP, Colpaert CG, et al. Increased angiogenesis and lymphangiogenesis in inflammatory versus noninflammatory breast cancer by realtime reverse transcriptase-PCR gene expression quantification. Clin Cancer Res 2004 Dec 1;10(23):7965-71.

[102] Camacho L, Pena L, Gonzalez GA, Caceres S, Diez L, Illera JC. Establishment and characterization of a canine xenograft model of inflammatory mammary carcinoma. Res Vet Sci 2013 Dec;95(3):106875.

[103] Camacho L, Pena L, Gil AG, Martin-Ruiz A, Dunner S, Illera JC. Immunohistochemical Vascular Factor Expression in Canine Inflammatory Mammary Carcinoma. Vet Pathol 2014;51:737-48.

[104] Horvath Z, Torday L, Hitre E, Ganofszky E, Juhos E, Czegledi F, et al. Inflammatory breast cancercomparing the effectivity of preoperative docetaxel-epirubicine protocol to conventional antracyclinecontaining chemotherapy to achieve clinical benefit and complete pathological response. Pathol Oncol Res 2011 Sep;17(3):541-50.

[105] Bourgier C, Pessoa EL, Dunant A, Heymann S, Spielmann M, Uzan C, et al. Exclusive alternating chemotherapy and radiotherapy in nonmetastatic inflammatory breast cancer: 20 years of follow-up. Int J Radiat Oncol Biol Phys 2012 Feb 1;82(2):690-5.

[106] Simon D, Schoenrock D, Baumgartner W, Nolte I. Postoperative adjuvant treatment of invasive malignant mammary gland tumors in dogs with doxorubicin and docetaxel. J Vet Intern Med 2006 Sep;20(5):1184-90.

[107] de M.Souza C, Toledo-Piza E, Amorin R, Barboza A, Tobias KM. Inflammatory mammary carcinoma in 12 dogs: clinical features, cyclooxygenase-2 expression, and response to piroxicam treatment. Can Vet J 2009 May;50(5):506-10.

[108] Clemente M, de Andres PJ, Pena L, Perez-Alenza MD. Survival time of dogs with inflammatory mammary cancer treated with palliative therapy alone or palliative therapy plus chemotherapy. Vet Rec 2009 Jul 18;165(3):78-81.

[109] Gregorio H, Prada J, Queiroga FL, Lobo L. Use of Firocoxib alone or in combination with metronomic Chlorambucil doses in macroscopic unresectable cancers in dogs. Proceedings of the European Society of Veterinary Oncology annual meeting; 2013 May 30: Lisbon. Royston, Nightingale Press, 2013, p.62.

[110] Monneur A, Bertucci F, Viens P, Goncalves A. Systemic treatments of inflammatory breast cancer: an overview. Bull Cancer 2014 Dec 1;101(12):1080-8.

[111] Yamauchi H, Cristofanilli M, Nakamura S, Hortobagyi GN, Ueno NT. Molecular targets for treatment of inflammatory breast cancer. Nat Rev Clin Oncol 2009 Jul;6(7):387-94.

[112] Robertson FM, Petricoin Iii EF, Van Laere SJ, Bertucci F, Chu K, Fernandez SV, et al. Presence of anaplastic lymphoma kinase in inflammatory breast cancer. Springerplus 2013;2:497.

[113] Nanda R, Chow LQ, Dees EC, Berger R, Gupta S, Geva R, et al. Pembrolizumab in Patients With Advanced Triple-Negative Breast Cancer: Phase Ib KEYNOTE-012 Study. J Clin Oncol 2016;34:2460-7.

[114] Schmid P, Cruz C, Braiteh FS, Eder JP, Tolaney S, Kuter I, et al. Abstract nr 2986: Atezolizumab in metastatic TNBC (mTNBC): Long-term clinical outcomes and biomarker analyses . AACR 2017, Washington, DC Philadelphia 2017.

[115] Varn FS, Mullins DW, Arias-Pulido H, Fiering S, Cheng C. Adaptive immunity programmes in breast cancer. Immunology 2017 Jan;150(1):25-34.

[116] Maekawa N, Konnai S, Okagawa T, Nishimori A, Ikebuchi R, Izumi Y, et al. Immunohistochemical Analysis of PD-L1 Expression in Canine Malignant Cancers and PD-1 Expression on Lymphocytes in Canine Oral Melanoma. PLoS One 2016;11(6):e0157176.

[117] Maekawa N, Konnai S, Ikebuchi R, Okagawa T, Adachi M, Takagi S, et al. Expression of PD-L1 on canine tumor cells and enhancement of IFN-gamma production from tumor-infiltrating cells by PDL1 blockade. PLoS One 2014;9(6):e98415.

[118] Beirao BC, Raposo T, Jain S, Hupp T, Argyle DJ. Challenges and opportunities for monoclonal antibody therapy in veterinary oncology. Vet J 2016 Dec 1;218:40-50. 
[119] Regan D, Guth A, Coy J, Dow S. Cancer immunotherapy in veterinary medicine: Current options and new developments. Vet J 2016 Jan;207:20-8.

[120] Dawood S, Ueno NT, Valero V, Woodward WA, Buchholz TA, Hortobagyi GN, et al. Differences in survival among women with stage III inflammatory and noninflammatory locally advanced breast cancer appear early: a large population-based study. Cancer 2011 May 1;117(9):1819-26.

[121] Dawood S, Broglio K, Gong Y, Yang WT, Cristofanilli M, Kau SW, et al. Prognostic significance of HER-2 status in women with inflammatory breast cancer. Cancer 2008 May 1;112(9):1905-11.

[122] Sutherland S, Ashley S, Walsh G, Smith IE, Johnston SR. Inflammatory breast cancer--The Royal Marsden Hospital experience: a review of 155 patients treated from 1990 to 2007. Cancer 2010 Jun 1;116(11 Suppl):2815-20.

[123] Nguyen DM, Sam K, Tsimelzon A, Li X, Wong H, Mohsin S, et al. Molecular heterogeneity of inflammatory breast cancer: a hyperproliferative phenotype. Clin Cancer Res 2006 Sep 1;12(17):504754.

[124] van Golen KL, Bao LW, Pan Q, Miller FR, Wu ZF, Merajver SD. Mitogen activated protein kinase pathway is involved in RhoC GTPase induced motility, invasion and angiogenesis in inflammatory breast cancer. Clin Exp Metastasis 2002;19(4):301-11.

[125] Kleer CG, Zhang Y, Pan Q, van Golen KL, Wu ZF, Livant D, et al. WISP3 is a novel tumor suppressor gene of inflammatory breast cancer. Oncogene 2002 May 9;21(20):3172-80.

[126] Muller A, Homey B, Soto H, Ge N, Catron D, Buchanan ME, et al. Involvement of chemokine receptors in breast cancer metastasis. Nature 2001 Mar 1;410(6824):50-6.

[127] Queiroga FL, Perez-Alenza MD, Gonzalez-Gil A, Silvan G, Pena L, Illera JC. Quantification of epidermal growth factor receptor (EGFR) in canine mammary tumours by ELISA assay: clinical and prognostic implications. Vet Comp Oncol 2017;15:383-90.

[128] Howe LR. Inflammation and breast cancer. Cyclooxygenase/prostaglandin signaling and breast cancer. Breast Cancer Res 2007;9(4):210.

[129] Harris RE, Casto BC, Harris ZM. Cyclooxygenase-2 and the inflammogenesis of breast cancer. World J Clin Oncol 2014 Oct 10;5(4):677-92.

[130] Singh B, Cook KR, Vincent L, Hall CS, Martin C, Lucci A. Role of COX-2 in tumorospheres derived from a breast cancer cell line. J Surg Res 2011 Jun 1;168(1):e39-e49.

[131] Clemente M, Sanchez-Archidona AR, Sardon D, Diez L, Martin-Ruiz A, Caceres S, et al. Different role of COX-2 and angiogenesis in canine inflammatory and non-inflammatory mammary cancer. Vet J 2013 Aug;197(2):427-32.

[132] Millanta F, Caneschi V, Ressel L, Citi S, Poli A. Expression of vascular endothelial growth factor in canine inflammatory and non-inflammatory mammary carcinoma. J Comp Pathol 2010 Jan;142(1):3642.

[133] Kolarevic D, Tomasevic Z, Dzodic R, Kanjer K, Vukosavljevic DN, Radulovic M. Early prognosis of metastasis risk in inflammatory breast cancer by texture analysis of tumour microscopic images. Biomed Microdevices 2015 Oct;17(5):92.

[134] Hall CS, Karhade M, Laubacher BA, Kuerer HM, Krishnamurthy S, DeSnyder S, et al. Circulating Tumor Cells and Recurrence After Primary Systemic Therapy in Stage III Inflammatory Breast Cancer. J Natl Cancer Inst 2015 Nov;107(11). 


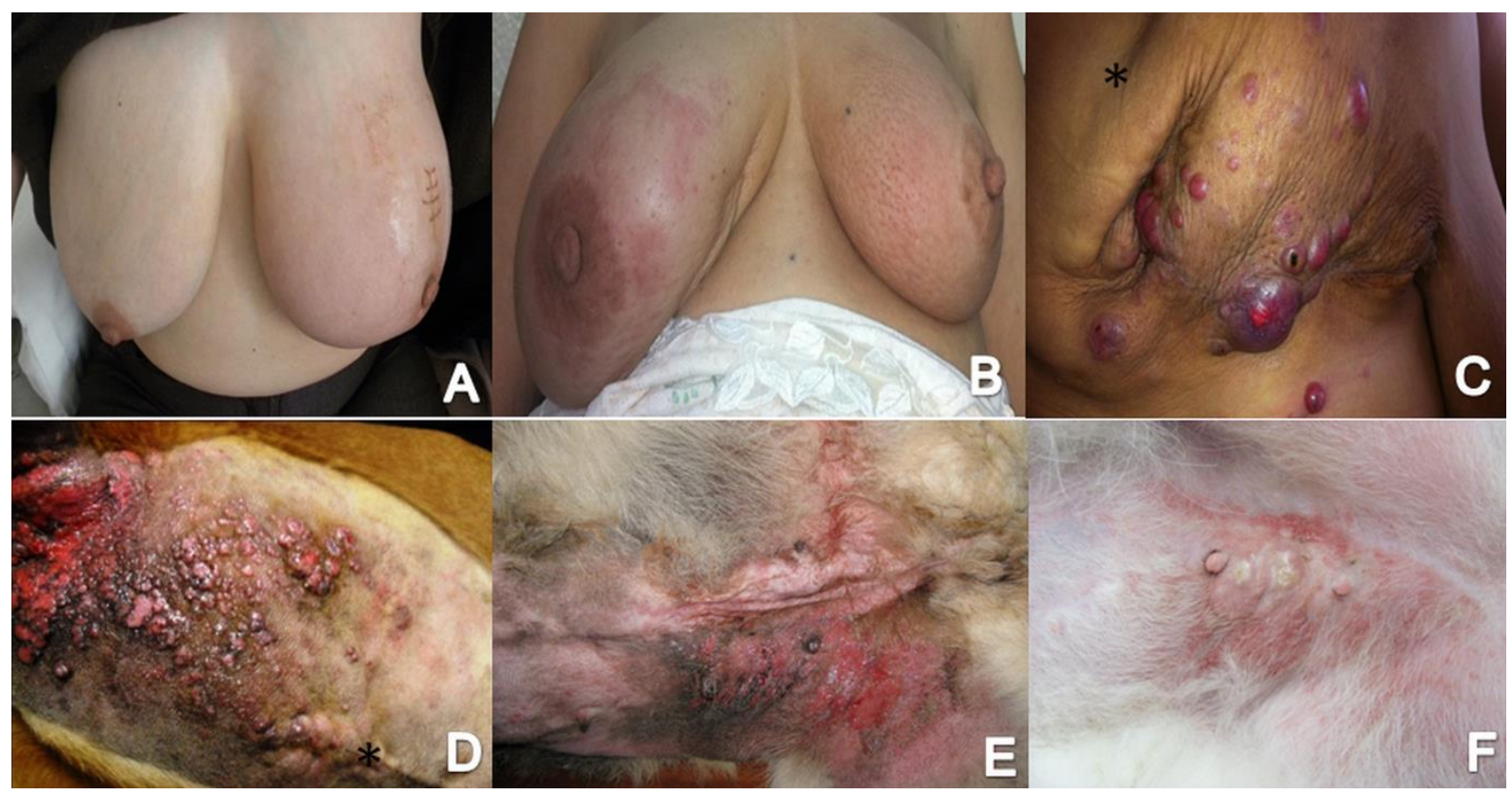

Figure 1 - Fig.1 - Clinical presentation of human IBC with redness, edema, and erythema; the site of the incisional biopsy is shown above the nipple (A). Bilateral IBC with similar symptoms as in A, and peau d'orange or orange peel appearance (B). Local recurrence of IBC. Note the scarf of the mastectomy from the primary IBC marked with an asterisk (C).Clinical presentation of canine IMC with extensive inflammation and edema of mammary (D) and inguinal region (E), and erythema and pustules (F). Secondary CIMC (previous incision marked with asterisk) (D) primary CIMC (E and F). 


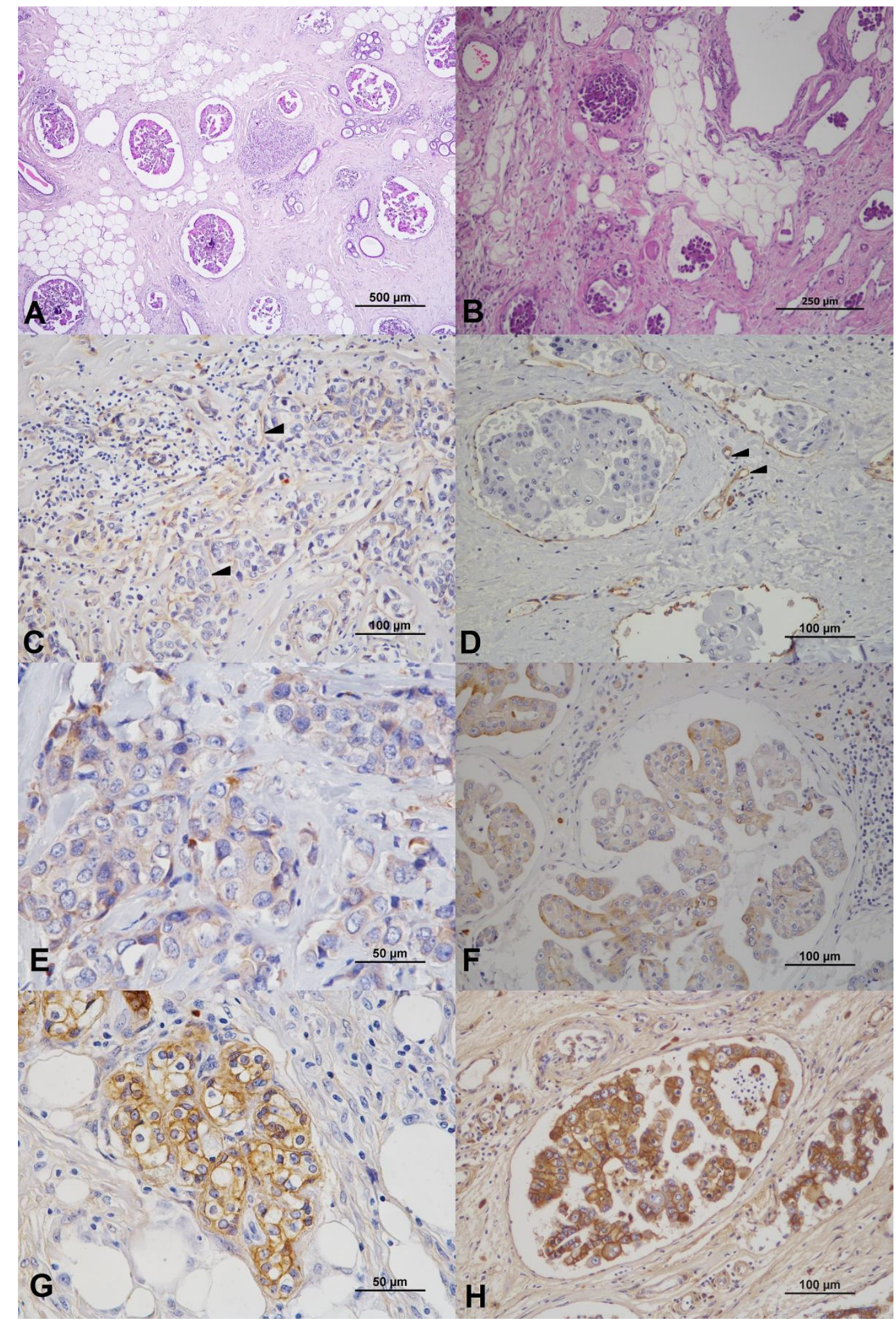

Fig.2 - Invasion of dermal lymphatic vessels by IBC (A) and CIMC emboli (B). CD31 expression in endothelial cells of lymphatic and blood vessels in IBC (C) and CIMC (D), indicated by arrowheads. COX-2 expression in IBC (E) and CIMC emboli (F). Expression of EGFR on the cell membrane and cytoplasm in IBC emboli (G) and CIMC emboli $(\mathrm{H})$. 
